\title{
DOCTRINAL CONTRIBUTIONS ON THE RIGHT TO USE THE WORK PROVIDED BY LAW NO. 8/1996
}

\author{
Tudor-Vlad SFÂRLOG \\ "Lucian Blaga" University in Sibiu, Romania \\ sfarlogb@yahoo.com
}

\begin{abstract}
In the present study we propose to offer a series of doctrinal solutions regarding the legal analysis of the patrimonial right to use the work of the authors, under Law no. 8/1996. The importance of the approach lies in the in-depth understanding of the institution, the logical and legal motivations of the Romanian legislator's options and the doctrinal and jurisprudential solutions in the field. Concerning the importance of legal protection of the author's patrimonial rights, we will mention here only the argument accepted by the opinionated that social development and well-being are inextricably linked to the legal protection of intellectual creation. We assume that the individual would not be encouraged to create in the absence of legitimate protection of the creation of his intellect.
\end{abstract}

\section{Keywords: patrimonial right, author's rights, protection}

\section{Introduction}

According to art.12 of the Law no. 8/1996 [1], "the author of a work has the exclusive property right to decide whether, how and when his work will be used, including consent to the use of the work by others." There are no ambiguities to the wording used by the legislator, in the context in which the provisions of Law no. 8/1996 are completed with the provisions of the Civil Code. Thus, according to art. 11 from the Civil Code: "It can not be derogated from, by unilateral conventions or legal acts, laws that concern public order or good morals". Obviously, the legal provision mentioned relates to public order. As stated [2], the civil law of public order orders or, as the case may be, extinguishes a legal act the application of which is useful or harmful to the entire society. At the same time, the exercise of the rights provided by art. 12 of the Law no. 8/1996 is made also in compliance with the provisions of art. 14 and 15 of the Civil Code, the holder of civil rights being obliged to exercise them in accordance with the principle of good faith, showing diligence in the form of a right intention, without seeking to prejudice any other subject of civil rights law [3]. Therefore, according to art. 12 of Law no.8/1996, the author can decide whether and how to use his work. By logically and legally analyzing the first sentence of the legal text, we deduct that the author has two possibilities, namely to use the work for patrimonial purposes or not to use it. However, it is questionable whether in fact the moral attribute of bringing the work to attention most of the times coincides with the patrimonial attribute of the use of the work, since it would be difficult, in breach of one of the author's prerogatives, not to violate the other. The paper raises interest from a doctrinal point of view regarding the monistic and dualist theories of the content of copyright as well as basically distinguishing $a b$ initio between the two attributes would mean that in the case of 
disobedience of the author's rights, sources, respectively disregarding the moral right provided by art. 10 par. a) and disregard of the patrimonial right provided by Article 12 of Law no. 8/1996. Actually, according to the principle of the protection of nonpatrimonial rights, art. 252 from the Civil Code states: "Every individual has the right to the protection of the intrinsic values of the human being, such as (...) freedom of conscience, scientific, artistic, literary or technical creation". Moreover, art. 253 of the Civil Code unequivocally regulates the active procedural means of the author in case of violation of his rights. The fair interpretation of the legislation of the Civil Code, art. 252 and 253 are corroborated with the provisions of Art. 2 of Law no.8/1996. At the same time, the reparation of the patrimonial damage provided under art. 12 is complied with in accordance with the general provisions of civil law on the compensation for property damage. Thus, the two types of liability are complementary to the protection of the legitimate moral and patrimonial interests of the author [4].

According to the last sentence of Article 12 of Law no. 8/1996, the author may consent to the use of the work by others. In our opinion, this is not an exception or a limitation on the exclusive patrimonial attributes of the author. On the contrary, the fact that the author can use the work for other purposes, through a convention, for the patrimonial purpose, strengthens and completes the exclusive character of patrimonial rights of the author.

Another aspect that can raise doctrinal discussion can be the meaning of the term "to use". According to the explanatory dictionary of the Romanian language, the meaning of "to use" is "to make use of, to employ". For a rigorous analysis of the construction used by the legislator, we refer to use as an attribute of ownership of the personal assets, iusutendi, and we will supplement it with the provisions of the copyright authority of Law no. 8/1996.
Thus, according to art.13 of Law no. 8/1996: "The use of a work gives rise to distinct and exclusive rights of the author to authorize or prohibit:

- reproduction of the work;

- distribution of the work;

- importing for the domestic market the copies made with the author's consent after the original work;

- renting the work;

- lending the work;

- the public communication, directly or indirectly, of the work by any means, including by making the work available to the public so that it can be accessed at any place and at any time, individually, by the public;

- the broadcasting of the work;

- broadcasting the work via cable transmission;

- the production of derivative works.

In Articles 14-16 of Law no. 8/1996, the legislator defines the attributes provided in art. 13 of the Law. The approach is commendable, in line with modern theories of law-making, creating predictability in law enforcement and ensuring a better understanding of the legal norm by direct beneficiaries. Thus, according to art. 14, reproduction involves the realization, in whole or in part, of one or more copies of a work, directly or indirectly, temporarily or permanently, by any means and in any form including the making of any sound or audiovisual recording of a work, as well as its permanent or temporary storage by electronic means. By the provision of art.14 of Law no. 8/1996, the legislator provides all the technical possibilities through which a piece of work can be reproduced, within the meaning of the law, anticipating that the law will be appropriate in the future in the context of technological evolution. According to Professor V. Roş [5], the French legislature has defined reproduction as the material fixation of the work by any method that allows it to communicate to the public in an indirect manner. It may be carried out, inter alia, by printing, drawing, 
engraving, photography, moulding and any other process of plastic art, mechanical, cinematographic or magnetic recording. For architectural works, reproduction is the repeated execution of a plan or a typical project. By comparing the two definitions, we find the main similarity that in both cases the legislator attempted to include all the technical possibilities of reproducing a work within the meaning of the copyright law, as evidenced by the broad and comprehensive enumerations. However, we believe that the definition given by the French legislator is of superior finesse, succeeding in setting two benchmarks of limiting the reproduction of the work. First of all, the French legislature refers only to the communication of the work to the public, in an indirect manner. This aspect has escaped the Romanian legislator and consists of the distinction between the reproduction of a work and its public communication, the second one being made directly. Secondly, the French legislator features the reproduction of works in the case of architectural works. Although we can not say that the Romanian legislator's definition is inadequate, the unauthorized reproduction of architectural works enjoying legal protection in the cases provided by the law, we consider that the definition given by the French legislator is more doctrinal than the legal consecration of reproduction of architectural works, makes the boundary between public communication and reproduction more inflexible.

According to art.142 paragraph (1) "distribution" means the sale or other means of transmission, whether by onerous title or free of charge, of the original or copies of a work and the public offering thereof. According to art.142 paragraph (2), the right of distribution shall be exhausted with the first sale or first transfer of ownership of the original or copies of a work on the domestic market by the right holder or with his consent. Thus, according to the legal regulation, the way in which property rights or the exercise of patrimonial rights are transferred is irrelevant. Clearly, we appreciate the fact that the legal text is declarative, and it is applicable regardless of how the property is acquired, including by inheritance. However, the construction used by the legislator, according to which the "right of distribution is exhausted" is criticized because the exhaustion of a right leads to the extinction of the right as such and not to its transmission, even if the distribution right disappears from the patrimony of the author. In other words, from the way in which legal regulation is formulated, we can deduce that exhaustion is relative to the law and not to the author. Or, by logically and legally analyzing the legal text, it would result that once the property is transmitted in any way, no subject of law would be the owner of the right to distribute the work. Obviously, such a suggestion contradicts elementary logic. In order to correct the legislative gap, we propose to amend Art. $14^{1.2}$ ) paragraph (2) as follows: Upon the first transfer of ownership of the original or of the legally executed copies of a work by the rightholder or with his consent, the right of distribution shall also be transferred.

According to art. $14^{2}$ of Law no.8/1996, import means the introduction on the domestic market, for the purpose of commercialization, of the original or legally produced copies of a work fixed on any kind of support. As the normative act provides, this notion of "import" is understood only in the meaning of Law no. $8 / 1996$, so only to works that have copyright. Thus, the legal provision derogates from the general rules strictly in the cases provided by the law. At the same time, according to the norm, the legal operation by which the works or, as the case may be, the legally executed copies are introduced into the internal civil circuit have a special purpose, namely to be valorized from the patrimonial point of view. Moreover, the wording in the last 
sentence of the article is declarative, the text of the law being applied in conjunction with Articles 2.3 of Law no. 8/1996 and the following.

According to art. $14^{3}$ of the Law no. 8/1996, renting means the making available for use for a limited time and for a direct or indirect economic or commercial advantage of a work. The analysis of the legal text reveals the following characteristics of the lease for the purpose of this law. First of all, the lease is to make available for use in the sense of the prerogative ius utendi, without altering the substance of the asset. Second, in terms of the scope of the contract, the lease of a work always has a fixed or determinable duration. Obviously, a contrary provision would harm not only the patrimonial rights of the author, but also the moral rights. Thirdly, the act of hiring a work has a special purpose, namely to obtain an economic or commercial advantage. Thus, the lease of a work is always forbidden, even if the legislature does not unequivocally specify which part of the contract draws up the act for the purpose of obtaining economic or commercial advantages, we reasonably infer that the party concerned is the author.

According to art. $14^{4}$ par. (1) "loan" means the making available for use, for a limited time and without a direct or indirect economic or commercial advantage of a work through an institution which allows public access for that purpose. First of all, the "making available for use" construction has the same uses as those used in the other provisions of Art. 14, the same meaning being made by the regulation on the temporal limitation of the loan. Second, the loan differs from rental for the special purpose. If, in the case of hiring, the act is drawn up in order to obtain economic or commercial advantages, the lending of a work is not intended to obtain direct or indirect economic or commercial advantages. Thirdly, we deduct from the statutory limitation rule that the loan is made only through an institution established for that purpose, which allows access to the public for the purpose of borrowing works. According to paragraph (2) of the same article, lending through libraries does not require the author's authorization and authorizes the author to a fair remuneration. We appreciate that authorizing the loan through libraries by the author would be inappropriate because the author consents a priori to the use of the work by libraries for the purpose of borrowing the work of the public. At the same time, the author's remuneration can be estimated based on the market value of the work and the time it is borrowed. According to paragraph (3), the author is not entitled to be remunerated if the loan is made through the libraries of the educational institutions and the public libraries with free access, and according to paragraph (4) of the same article, the lending of works recorded in sound or audiovisual recordings may not take place less than 6 months after the first distribution of the work. Thus, the legal regulation in paragraph (4) protects the patrimonial rights of the author in view of the facility by which the sound or audiovisual works can be multiplied without counting the author's rights by setting a period within which the author can not borrow the work. At the same time, the legal regulation is not suppressive, the parties being unable to derogate from the legal provisions by other acts.

According to art. 15, public communication consists of any communication of a work, made directly or by any technical means, made in a place open to the public or in any place where a number of persons are gathered beyond the normal circle of members of a family and acquaintances, including stage representation, recitation, or any other public way of performance or direct presentation of the work. Public communication and public display of works of fine arts, applied art, photographic and architectural works, public projection of cinematographic works and other 
audiovisual works, including works of digital art, presentation in a public place, by means of sound recordings or audiovisual media, as well as the presentation in a public place, by any means, of a broadcasting work. At the same time, any communication of a work, whether by wire or wireless means, achieved by making it available to the public, including via the Internet or other computer networks, shall be publicly disclosed in such a way that any member of the public can access it from any place or at any time individually chosen.

On the other legal provisions of art. 15-16 there is no special mention, the legislator's definitions being clear enough. This is also the case for the doctrine in the field, and there is no ambiguity.

Therefore, by this scientific approach, we believe we have succeeded in bringing a number of arguments in favor of the various doctrinal approaches to the law of legally protected works to be used for patrimonial purposes and to contribute to better legal protection of these rights.

\section{Conclusions}

By this scientific approach we consider that we have managed to bring a series of doctrinal solutions to the different approaches in the field and a series of recommendations de lege ferenda to the Romanian legislator in the area of the patrimonial right of the author to use his work, with emphasis on the provisions of art. $14^{1}$ of Law no. 8/1996. The presentation of the various doctrinal approaches and their completion takes advantage of the direct beneficiaries of the present study, providing assistance in the effort to understand the provisions of Law no. $8 / 1996$ and to carry out their creative activity in the context of predictability. In this respect, we believe that we succeeded in contributing, through the suggestion addressed to the Romanian legislator, to the creation and implementation of a legal framework conducive to creative activity, ensuring legal protection equitable to the legitimate interests of copyright holders and copyright related rights.

\section{References}

[1] Legea nr. 8/1996 a fost publicată în M.Of. nr. 60, Partea I,din 26 martie 1996 şi a fost modificată prin următoarele acte: Legea nr. 285/2004; OUG 123/2005; OUG 190/2005; DCZ 571/2010; Legea nr. 202/2010; Legea nr. 71/2011; OUG nr. 71/2011; Legea nr. 146/1997; Legea nr. 187/2012; Legea nr. 76/2012; Legea nr. 255/2013; Legea nr. 53/2015; Legea nr. 210/2015.

[2] E. Heroveanu, Tratat teoretic și practic de procedură civilă, Institutul de Arte Grafice "Viața Românească", Iași, 1926, p.57 and next.

[3] F.A. Baias, E. Chelaru, R. Constantinovici, I. Macovei (coord.), Noul Cod civil. Comentariu pe articole, art. 1-2664, Ed. Ch. Beck, București, 2012, pp.14,15,654.

[4] Fr. Deak, S.D. Cărpenaru, Drept civil. Contractele speciale. Dreptul de autor. Dreptul de moștenire, Universitatea București, 1983, p. 339 and next.

[5] V. Roș, Dreptul proprietății intelectuale. Curs universitar, Ed. Global Lex, București, 2001, p. 130. 